Calcium Content of the Sclerotic

\title{
THE CALCIUM CONTENT OF THE SCLEROTIC AND ITS VARIATION WITH AGE
}

\author{
BY \\ Arnold Sorsby, Kathleen Wilcox and Dora Ham \\ LONDON
}

\section{Morphological Considerations. ${ }^{1}$}

Unlike the auditory and olfactory organs, the visual apparatus throughout the vertebrate kingdom does not become encased by bone, itself part of the cranium. Except in some cartilaginous fishes (selachii) the sclerotic coat of the eye is not attached to the skull; where such attachment is present it is by means of a cartilaginous rod joining the sclera to the skull, and developed to a varying degree in different species. The protective covering of the eye is therefore free practically throughout the vertebrate phyllum, but it varies widely in structure in the different classes of vertebrates. Thus in Fishes the sclerotic is fibrous in lampreys, and almost exclusively cartilaginous (with calcification as a senescent change) in Selachii as also in Ganoidei (fishes with enamelled scales or dermal plates), whilst in Teleostei (bony fishes) the sclerotic may be purely fibrous, or fibrous and cartilaginous, or fibrous, cartilaginous and bony, and finally fibrous and bony only; in Dipnoi ("lung fishes") the sclera contains cartilage reaching up to the equator. In Amphibia a fibrous sclerotic is present in many urodela (amphibia in which the larval tail persists in the adult) but some, such as the cryptobranchus, have cartilage of monstrous thickness ; in the frog cartilage is present and reaches up to the insertion of the extra-ocular muscles. In Reptilia, the sclerotic generally consists of fibrous tissue and cartilage but it is purely fibrous in snakes, whilst in lizards and turtles bony deposits are present; where cartilage is present in reptiles it varies greatly in thickness at different sites; the fossil skeleton of Ichthyosaurus shows a bony scleral ring. Birds too show considerable variations in the structure of the sclera, fibrous tissue playing the least part in the conformation of the globe; where cartilage is present it is generally thin, and bone is frequently seen towards the limbus and around the entry of the optic nerve ("optic nerve bones"); occasionally the bone takes complicated forms, a rooftile formation sometimes being present; thick, well differentiated bone is present in all nocturnal birds of prey and in the larger diurnal birds of that kind. It is only in mammals, with the exception of the monotremes, that a purely fibrous sclerotic is present throughout: in the monotremes cartilage like other reptilian characteristics, is present. The fibrous sclera of mammals shows great variations in different orders; it is exceptionally thick in whales. 
Whatever the reason for these variations-and no satisfactory explanation is forthcoming for the apparently planless variation in structure-cartilage and bone loom large in the morphological history of the sclerotic. The calcium content of the human sclerotic may therefore present features of interest, whilst a comparison with other tissues as to the variation of the calcium contents with age should also not be devoid of interest.

2. Variations in the Calcium Content of Tissues with Age.

(1) Total Calcium Content of body.

Calcium rises progressively during foetal life and in extrauterine life till an adult level is reached and remains constant. This increase is shown by the following summary table, giving the percentage of calcium on a fat-free basis. ${ }^{2}$

\begin{tabular}{|c|c|c|c|c|c|c|}
\hline & & & & & Embryo & Adul \\
\hline & Man & $\begin{array}{l}\text { (a) } 3 \\
\text { (b) } 3\end{array}$ & $\begin{array}{l}\text { ays } \\
\text { nonths }\end{array}$ & $\begin{array}{l}\ldots \\
\ldots\end{array}$ & $\begin{array}{l}0^{\circ} 001 \\
1.73\end{array}$ & (?) $9^{\circ} 4$ \\
\hline Guinea-I & -pig & $\cdots$ & $\ldots$ & $\ldots$ & 1.57 & $4^{\circ} 8$ \\
\hline Rabbit. & $\ldots$ & $\ldots$ & $\ldots$ & $\ldots$ & $1^{\circ} 43$ & \\
\hline Rat & $\ldots$ & $\ldots$ & $\ldots$ & $\ldots$ & $1 \cdot 50$ & \\
\hline Mouse . & $\ldots$ & $\ldots$ & $\ldots$ & $\ldots$ & $1 \cdot 14$ & \\
\hline Dog & $\because$ & $\ldots$ & $\ldots$ & $\ldots$ & $2 \cdot 24$ & \\
\hline Cat & $\cdots$ & $\ldots$ & $\ldots$ & $\ldots$ & 261 & \\
\hline
\end{tabular}

For the white rat Sherman and MacLeod ${ }^{3}$ give the following data as to the increase of the calcium content in extra-uterine life :-

\begin{tabular}{|c|c|c|c|c|c|}
\hline At birth & $\cdots$ & & .. & & 0.25 per cent. \\
\hline At 15 days & $\cdots$ & $\cdots$ & $\ldots$ & $\ldots$ & 0.60 \\
\hline At 30 days & . & $\ldots$ & $\ldots$ & $\ldots$ & 0.70, \\
\hline At 60 days & $\ldots$ & $\ldots$ & $\ldots$ & $\ldots$ & 0.85, \\
\hline At 90 days & $\ldots$ & $\ldots$ & $\ldots$ & $\ldots$ & $0.95-1.1$ per cer \\
\hline Adult & $\ldots$ & $\ldots$ & $\ldots$ & $\ldots$ & $1^{\circ} 0-1^{\circ} 2$ \\
\hline
\end{tabular}

(2) Calcium Content of individual organs.

(a) Bone :-As calcium in the body is largely stored in the bones, it would appear that the data given for the total calcium content of the body apply in general to the bony system.

(b) Muscle :-The calcium content of muscle varies with different animals and with different muscles for the same animal. (Katz ${ }^{4}$ gives the calcium value for muscle of different mammals as $2-18 \mathrm{mgm}$. per cent.; Heubner and Rona give a variation of between 3-18 mgm. per cent. for different muscles of the cat). Human muscle shows a decrease of calcium content with age, as is shown by the following table giving percentage of $\mathrm{CaO}$ present : $\leftarrow^{5}$ 


$\begin{array}{lcccccc}\text { Premature birth }(7 \text { months }) & \ldots & \ldots & \ldots & 0.03 \\ \text { At } 4 \text { years } & \ldots & \ldots & \ldots & \ldots & \ldots & 0.01 \\ \text { Adult } \quad \ldots & \ldots & \ldots & \ldots & \ldots & \ldots & 0.01\end{array}$

Contrary percentages are given for muscle of the $\mathrm{dog}: \mathbf{-}^{6}$

$\begin{array}{lllllll}\text { At } 1 \text { month } & \ldots & \ldots & \ldots & \ldots & \ldots & 0 \\ 0 & 010\end{array}$

$\begin{array}{lllllll}\text { Adult } \ldots & \ldots & \ldots & \ldots & \ldots & \ldots & \\ & & \ldots & \ldots & \ldots & \end{array}$

(c) Brain :-A marked decrease in the calcium content of the human brain occurs with age. ${ }^{\text {? }}$

Percentage of calcium in dry substance of brain :-

\begin{tabular}{lcccccc}
\multicolumn{2}{l}{ Seven months fottus... } & $\ldots$ & $\ldots$ & $\ldots$ & 0 \\
At birth & $\ldots$ & $\ldots$ & $\ldots$ & $\ldots$ & $\ldots$ & 0.108 \\
At 8 years & $\ldots$ & $\ldots$ & $\ldots$ & $\ldots$ & $\ldots$ & 0.051
\end{tabular}

(d) Human intestine and liver also show a decrease, falling from 0.02 per cent. at birth to 0.01 per cent at 4 years. ${ }^{8}$ On the other hand, lung and heart show an increase in comparing analyses obtained from tissue 9 weeks and $2 \frac{1}{2}$ years old :- lung rises from 0.010 to 0.014 and heart from 0.014 to 0.023 per cent. ${ }^{\circ}$

(e) Blood :- That calcium in whole blood and serum decreases with age has been reported by a number of observers. Reviewing the literature and drawing on their own work Greisheimer, Johnson and Ryan" conclude the "calcium content [of serum] definitely decreases with age; in women it falls from an empirical average of $11.8 \mathrm{mg}$. at the age of 12 vears to $9.7 \mathrm{mg}$. at the age of 78 . In men it falls from $11.6 \mathrm{mg}$. at the age of 12 to $10.0 \mathrm{mg}$. at the age of 78." This sex difference they did not find to be statistically significant.

The decrease in calcium in tissues with age has been stressed by C. I. Parhon and M. Parhon. ${ }^{11}$ They give the following results for muscle tissue and blood.

$$
\begin{array}{cccccc} 
& & \multicolumn{3}{c}{\text { Ca per } 1,000 \text { of dried tissue }} \\
\text { Blood } & \begin{array}{c}
\text { Muscle } \\
\text { Guinea-pig : } 2.1 \text { months }
\end{array} & \ldots & \ldots & 0^{*} 40 & 1^{\circ} 08 \\
34 \text { months } & \ldots & \ldots & 0^{\circ} 29 & 0^{\circ} 53 \\
\text { Rabbit : } 1 \text { month ... } & \ldots & \ldots & 0^{\circ} 45 & 1^{\circ} 40 \\
24 \text { months } & \ldots & \ldots & 0.31 & 0^{\circ} 62
\end{array}
$$

Their results have been confirmed by Cahane ${ }^{12}$ who supports their view that the decrease in calcium in tissues with age is accompanied by a loss of water, Calcium acting as a hydrating agent.

\section{The Calcium Content of the Sclerotic and its Variation with Age.}

Three series of investigations were undertaken. The calcium content of the sclerotic of cats of different ages and in a series of human sclerotics was determined by one of us (K. W.) whilst 
a parallel series of human sclerotics was studied by a second observer (D. H.). The methods employed and the detailed results are given in the appendix. The findings are shown in the following summary table.

\section{SCLEROTIC OF CAT}

\begin{tabular}{|c|c|c|c|c|c|}
\hline \multicolumn{4}{|l|}{$\begin{array}{l}\text { Estimated age } \\
\text { of animal }\end{array}$} & $\begin{array}{l}\text { Number of } \\
\text { sclerotics }\end{array}$ & $\begin{array}{l}\text { Mean Ca. mg. per } \\
100 \mathrm{gm} \text {. dried tissue }\end{array}$ \\
\hline Newborn & $\ldots$ & & & 13 & 108 \\
\hline One month & $\ldots$ & .. & & 26 & 69 \\
\hline Intermediate $\mathrm{b}$ & ween & $-3 n$ & ths & 17 & 60 \\
\hline $\begin{array}{l}\text { Three months } \\
\text { Intermediate }\end{array}$ & $\begin{array}{l}\ldots \\
\text { tween }\end{array}$ & $3 \mathrm{n}$ & $\begin{array}{l}\ldots \\
\text { ths }\end{array}$ & 17 & 51 \\
\hline and half & own & $\ldots$ & $\ldots$ & 7 & 46 \\
\hline Half grown & & $\ldots$ & $\ldots$ & 15 & 43 \\
\hline Young adult & $\ldots$ & $\ldots$ & $\ldots$ & 13 & 50 \\
\hline Older adult & $\ldots$ & $\ldots$ & $\ldots$ & 2 & 59 \\
\hline Old ... & $\ldots$ & $\ldots$ & $\ldots$ & 3 & 67 \\
\hline Very old $\ldots$ & $\ldots$ & $\ldots$ & $\ldots$ & 1 & 95 \\
\hline
\end{tabular}

Human SClerotics-First series (K.W.)

\begin{tabular}{|c|c|c|c|c|c|c|}
\hline \multicolumn{2}{|c|}{ Age in years } & \multicolumn{4}{|r|}{$\begin{array}{l}\text { Number of } \\
\text { sclerotics }\end{array}$} & $\begin{array}{l}\text { Mean Ca.m } \\
100 \text { gm. drie }\end{array}$ \\
\hline $9 / 12$ to & $\ldots$ & $\cdots$ & $\cdots$ & $\cdots$ & 8 & $9+$ \\
\hline $5-10$ & $\ldots$ & $\ldots$ & $\ldots$ & $\ldots$ & 2 & 108 \\
\hline $10-20$ & $\ldots$ & $\ldots$ & $\ldots$ & $\ldots$ & 10 & 115 \\
\hline $20-30$ & $\ldots$ & $\ldots$ & $\ldots$ & $\ldots$ & - & - \\
\hline $30-40$ & $\ldots$ & $\ldots$ & $\ldots$ & $\ldots$ & 2 & 149 \\
\hline $40-50$ & $\ldots$ & $\ldots$ & $\ldots$ & $\ldots$ & 4 & 218 \\
\hline $50-60$ & $\ldots$ & $\ldots$ & $\ldots$ & $\ldots$ & 3 & 425 \\
\hline \multicolumn{7}{|c|}{ Second series (D.H.) } \\
\hline Up to 1 & $\ldots$ & $\ldots$ & $\ldots$ & $\ldots$ & 18 & 57 \\
\hline $1-5$ & $\ldots$ & $\ldots$ & $\ldots$ & $\ldots$ & 5 & 65 \\
\hline $5-10$ & $\ldots$ & $\ldots$ & $\ldots$ & $\ldots$ & 9 & 68 \\
\hline $10-20$ & $\ldots$ & $\ldots$ & $\ldots$ & $\ldots$ & 4 & 81 \\
\hline $20-30$ & $\ldots$ & $\cdots$ & $\ldots$ & $\ldots$ & 8 & \\
\hline $30-40$ & $\ldots$ & $\ldots$ & $\ldots$ & $\ldots$ & 10 & 7 \\
\hline $40-50$ & $\ldots$ & $\ldots$ & $\ldots$ & $\ldots$ & 19 & 202 \\
\hline 50 upwar & & $\ldots$ & $\ldots$ & $\ldots$ & 25 & 262 \\
\hline
\end{tabular}

The results for human sclerotic are shown graphically in the following curve. They illustrate a slow rise in calcium till about the age of 30 with an abrupt and continuous rise after that age.

It will be seen that the curves have the same general course but different actual values. The different methods employed and the use of platinum crucibles in one series and silica crucibles in the other may explain the numerical difference in the results obtained. 


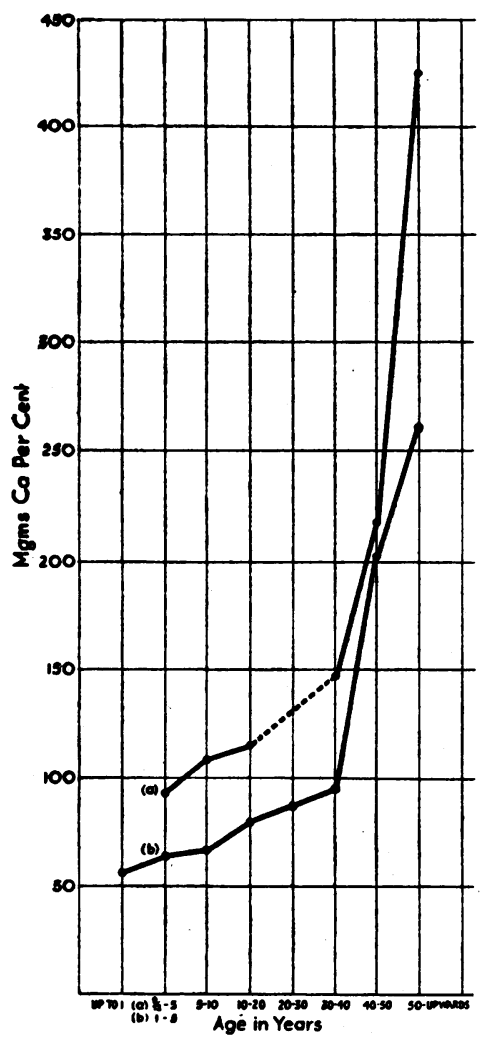

THE VARIATION WITH AGE OF THE CALCIUM CONTENT OF THE SCLEROTIC.

The upper graph represents the findings in the first series (K.W.), the lower graph in the second (D.H.).

\section{Discussion.}

These investigations were undertaken to elucidate the problem as to whether a calcium deficiency in the sclerotic might be a factor in the genesis of myopia, an oft-advanced hypothesis which views myopia as a sort of scleral rickets. It cannot be said these results achieve the purpose indicated. Conclusions could only be drawn if comparative data of the calcium content of the sclerotic of known progressive myopic eyes could be submitted. In the nature of things such material is unlikely to be gathered except by the concerted efforts of many observers.

The results submitted do however give some indication as to the normal metabolism of the calcium in the sclerotic and the abrupt rise in the calcium content after middle-age may be of significance in the aetiology of glaucoma.

\section{Summary}

1. The morphology of the sclerotic would indicate that calcium is a factor of some significance in the history and possibly the composition of the human sclerotic. 
2. Results are given showing that compared to muscle the sclerotic is not excessively rich in calcium.

3. In the sclerotic of the cat calcium was found to decrease progressively from birth till adult life, and to rise subsequently with increasing age.

4. In man the calcium content of the sclerotic rises slowly till about the age of 30 , and very abruptly after that.

5. This behaviour is in marked contrast to the progressive decrease with age given by other observers for most. other tissue.

6. The possible significance of the results in the genesis of myopia and of glaucoma is indicated.

We wish to express our indebtedness to the late Professor $\mathbf{R}$. Donaldson who had kindly put the post-mortem material of Guy's Hospital at our disposal, and to Dr. D. N. Nabarro for a like service at the Hospital for Sick Children, Great Ormond Street. To Dr. J. H. Ryffel of the Clinical Chemistry Dept. of Guy's we are indebted for the facilities of his laboratory whilst to Dr. W. W. Payne, we are obliged for his kindly interest, helpful criticism and the facilities of his department of Bio-Chemistry at the Hospital for Sick Children. To the Brit. Jl. of Ophthal. we are indebted for a grant to cover expenses.

\section{REFERENCES}

1. Franz, V.-Sehorgan in Albert Oppel's Lehrbuch der vergleichenden mikroskopischen Anatomie der Wirbeltiere. Siebenter Teil, pp. 288-98. Jena, 1913.

Kingsley, J. S. - Outlines of Comparative Anatomy of Vertebrates. London, 1926.

2. Moulton.-Journ. of Biolog. Chem., Vol. LVII, p. 79, 1923.

3. Sherman and Macleod.-Ibid. Vol. LXIV, p. 429, 1925.

4. Quoted in Handbuch der normalen und pathologischen Physiologie. Berlin, 1931. Bd. XVI/2, S. 1490.

5. For full references giving sources see H. Aron, Biochemie des Wachstums des Menschen und der höhern. Tiere in Handbuch der Biochemie des Menschen und der Tiere. Ergänzungsband. Jena, 1913. P. 627.

6. Ibid P. 627.

7. Ibid. P. 633.

8. Ibid. P. 630 .

9. Ibid. P. 630

10. Greisheimer, Johnson and Ryan.-Amer. Jl. of the Med. Sciences, Vol. CLXXVII, p. 704, 1929.

11. Parhon, C. I., and Parhon, M. I.-Comptes rend. Soc. de Biol., Vol. Jubilaire, Paris p. 46, 1923.

12. Cahane.-Ibid. Vol. XCVI, p. 1168, 1927.

\section{Appendix}

1. Preparation of Material :-

(a) Sclerotic of cat. The animals were obtained from a dealer who delivered them within 12 hours of their being killed in station for stray and unwanted cats and dogs. The eyes were removed in toto, the optic nerve cut flush with the sclerotic, adherent muscle and orbital contents removed, the cornea abscised completelv 
and the interior of the opened eye scraped as clean as possible, but not washed. An absolutely white surface could not always be obtained, as pigment seems to be incorporated in the sclera of some cats.

(b) Human sclerotic. After removing the brain, the roof of the orbit was opened, care being taken to avoid splintering and scattering of bone dust. As much as possible of the posterior segment of the globe was removed, leaving the cornea and iris in situ.

\section{Methods of estimating the Calcium :-}

(a) Cats' and first series of human sclerotic (K. W.).

The material was dried to constant weight in a steam oven and ashed in a platinum crucible. The ash was dissolved in 1 c.c. concentrated hydrochloric acid and the solution transferred to a conical centrifuge-tube. The $P_{h}$ was then adjusted and the calcium determined by precipitating it as oxalate, washing it three times with 2 per cent. ammonia solution, dissolving in dilute sulphuric acid and titrating with $\mathrm{N} / 100$ potassium permanganate whilst hot.

(b) Human sclerotics (second series, D. H.).

The material was dried as in the previous method but ashed in silica crucibles as platinum was not available. The ash was dissolved in 0.5 c.c. Normal $\mathrm{HCl}$, which was evaporated off on a boiling water bath. The residue was redissolved in 0.5 c.c. $\mathrm{N} / 10$ $\mathrm{HCl}$ and washed into a special 4 c.c. hard glass centrifuge tube with 3 lots of dist. water $0.5,0.3$ and 0.2 c.c. respectively. This solution was then neutralised with Normal $\mathrm{NaOH}$ using Phenol Red as indicator and the tube then filled with a saturated solution of ammonium oxalate mixed and allowed to stand overnight. In the morning the tubes were centrifuged for 20 minutes, the supernatent fluid removed by means of a suction pump and the precipitate washed with 2 c.c. of saturated ammonium oxalate solution (without disturbing precipitate) and centrifuged for another 5 minutes. This washing was carried out three times. After the final removal of the supernatent fiuid the tubes were dried in a water oven and then heated in a flame driving off the ammonium oxalate, and decomposing the calcium oxalate to carbonate, overheating being avoided. When cool the residue was dissolved in 1 c.c. of $\mathrm{N} / 50 \mathrm{HCl}$ and back titrated to $\mathrm{P}_{h} 4.0$ with $\mathrm{N} / 50 \mathrm{NaOH}$ in a micrometer syringe (Trevan) using 075 c.c. of Brom. Phenol Blue as indicator.

3. Detailed Results :-
(a) Cats.
(b) Human (First series, K. W.).
(c) Human (Second series, D. H.). 
(a) CATS (K.W.)

These sclerotics were analysed in batches of approximately the same age.

\begin{tabular}{|c|c|c|c|c|}
\hline \multicolumn{2}{|c|}{ Estimated age } & $\begin{array}{l}\text { No. sclerotics } \\
\text { in batch }\end{array}$ & $\begin{array}{c}\text { Calcium mgm. per } \\
100 \mathrm{gm} \text {. dried tissue }\end{array}$ & Mean \\
\hline Newborn & $\ldots \quad \ldots$ & 13 & 108 & 108 \\
\hline 1 month & $\ldots$ & $\begin{array}{l}6 \\
6 \\
8 \\
6\end{array}$ & $\begin{array}{l}71 \\
69 \\
69 \\
70\end{array}$ & $6^{\circ}$ \\
\hline $\begin{array}{r}\text { Intermediate } \\
1 \text { and } 3 \mathrm{~m}\end{array}$ & $\begin{array}{l}\text { between } \\
\text { conths }\end{array}$ & $\begin{array}{r}5 \\
12\end{array}$ & $\begin{array}{l}63 \\
58\end{array}$ & 60 \\
\hline 3 months & $\cdots$ & $\begin{array}{l}3 \\
3 \\
5 \\
6\end{array}$ & $\begin{array}{l}50 \\
51 \\
52 \\
54\end{array}$ & 51 \\
\hline $\begin{array}{l}\text { Intermediate } \\
3 \text { months } \\
\text { grown }\end{array}$ & $\begin{array}{l}\text { between } \\
\text { and half }\end{array}$ & $\begin{array}{l}4 \\
3\end{array}$ & $\begin{array}{l}47 \\
46\end{array}$ & 46 \\
\hline Half grown & $\ldots$ & $\begin{array}{l}2 \\
3 \\
4 \\
4 \\
2\end{array}$ & $\begin{array}{l}47 \\
42 \\
40 \\
39 \\
50\end{array}$ & 43 \\
\hline Young adult & $\ldots$ & $\begin{array}{l}1 \\
1 \\
2 \\
2 \\
2 \\
2 \\
1 \\
1 \\
1\end{array}$ & $\begin{array}{l}55 \\
51 \\
53 \\
62 \\
47 \\
44 \\
45 \\
48 \\
46\end{array}$ & 50 \\
\hline Older adult & $\ldots$ & $\begin{array}{l}1 \\
1\end{array}$ & $\begin{array}{l}59 \\
59\end{array}$ & 59 \\
\hline Old $\ldots$ & $\cdots$ & $\begin{array}{l}1 \\
1 \\
1\end{array}$ & $\begin{array}{l}77 \\
70 \\
55\end{array}$ & 67 \\
\hline Very old & $\ldots$ & 1 & 95 & 95 \\
\hline
\end{tabular}


Calcium Content of the Sclerotic

(b) HUMAN (First series, K.W.)

\begin{tabular}{|c|c|c|c|}
\hline Age in years & $\begin{array}{l}\text { Calcium mgm. per } \\
100 \mathrm{gm} \text {. dried tissue }\end{array}$ & Mean & \\
\hline$\frac{9}{12}$ & 86 & 86 & \\
\hline $1_{1}^{1} \frac{1}{2}$ & $\begin{array}{l}92 \\
90\end{array}$ & 91 & \\
\hline $1 \frac{9}{1 \bar{z}}$ & $\begin{array}{r}92 \\
108\end{array}$ & 100 & \\
\hline 5 & $\begin{array}{r}105 \\
103 \\
95\end{array}$ & 101 & \\
\hline $7 \frac{6}{12}$ & 107 & 107 & \\
\hline 8. & 110 & 110 & \\
\hline 11 & 99 & 99 & \\
\hline $13_{1}^{6} \cdot \overline{2}$ & $\begin{array}{l}79 \\
74\end{array}$ & 76 & \\
\hline 15 & $\begin{array}{l}130 \\
120\end{array}$ & 125 & \\
\hline 16 & $\begin{array}{l}100 \\
100 \\
141\end{array}$ & 113 & \\
\hline 18 & 128 & 128 & \\
\hline 19 & 148 & 148 & \\
\hline 34 & $\begin{array}{l}144 \\
155\end{array}$ & 149 & \\
\hline 43 & 206 & 206 & ' \\
\hline 44 & 210 & 210 & \\
\hline 47 & $\begin{array}{l}250 \\
230\end{array}$ & 240 & \\
\hline 53 & $\begin{array}{l}390 \\
410\end{array}$ & 400 & \\
\hline 60 & 450 & 450 & \\
\hline
\end{tabular}

As the calcium content varied considerably with sclerotics of the same age, the results, for plotting purposes, were divided into groups.

\begin{tabular}{c|c|c}
\hline Age in years & No. determinations & Calcium \\
\hline 9 & 8 & 94 \\
$1 \overline{2}^{-}-5$ & 2 & 108 \\
$6-10$ & 10 & 115 \\
$10-20$ & Nil & - \\
$20-30$ & 2 & 149 \\
$30-40$ & 4 & 218 \\
$40-50$ & 3 & 425 \\
$50-60$ & & \\
\hline
\end{tabular}




\begin{tabular}{|c|c|c|}
\hline \multirow{4}{*}{ مُ } & 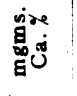 & 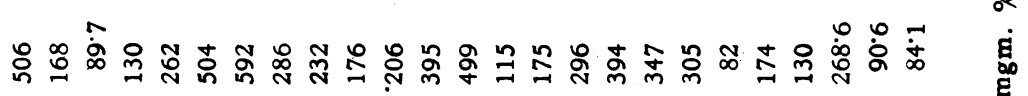 \\
\hline & 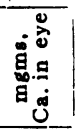 & 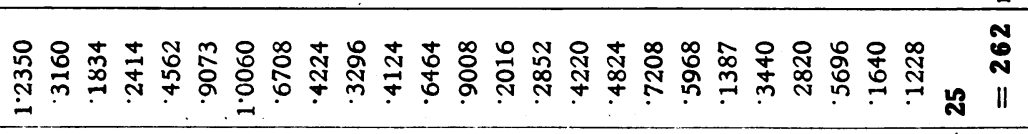 \\
\hline & 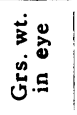 & 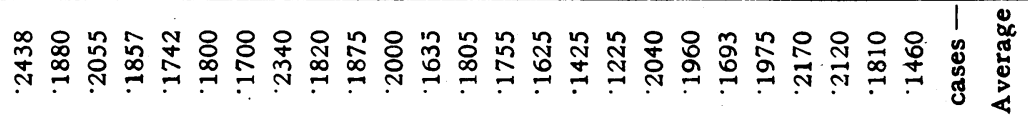 \\
\hline & 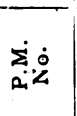 & 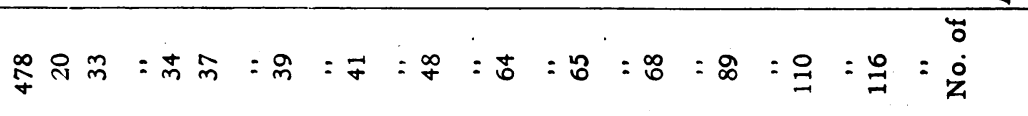 \\
\hline \multirow{4}{*}{$\begin{array}{l}\mathrm{d}_{0}^{2} \\
\vdots \\
\vdots \\
\vdots\end{array}$} & 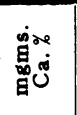 & 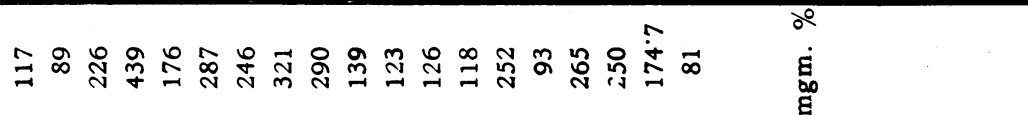 \\
\hline & 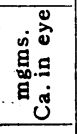 & 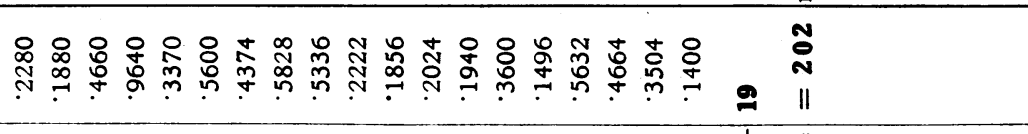 \\
\hline & 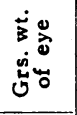 & 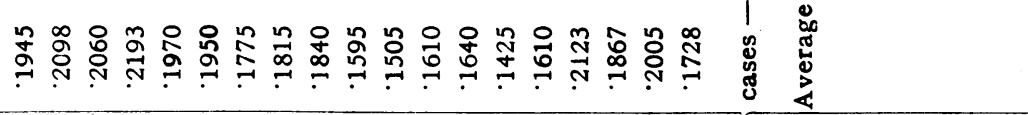 \\
\hline & sid & 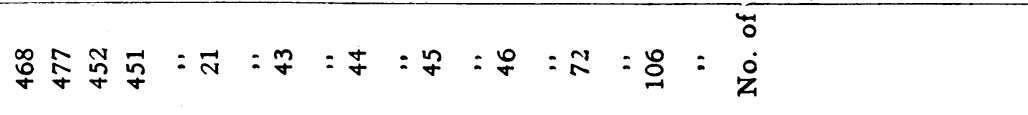 \\
\hline \multirow{4}{*}{$\begin{array}{l}0 \\
0 \\
0 \\
0 \\
0 \\
0 \\
0\end{array}$} & 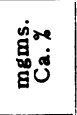 & 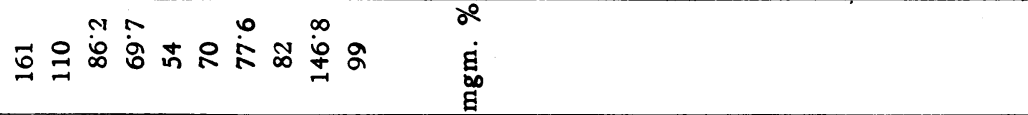 \\
\hline & 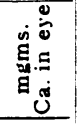 & 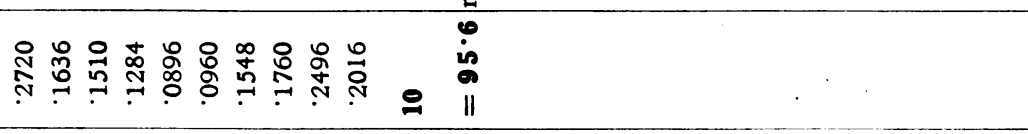 \\
\hline & 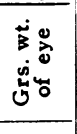 & 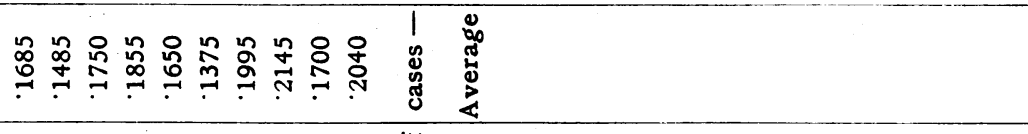 \\
\hline & 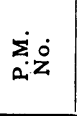 & 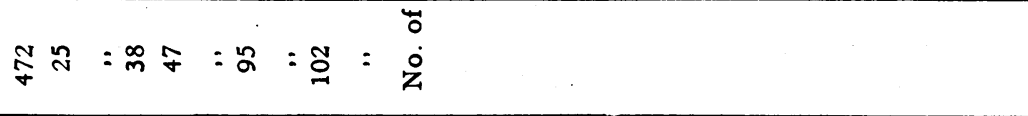 \\
\hline \multirow{4}{*}{ 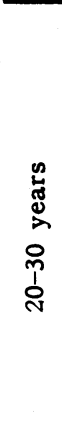 } & 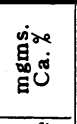 & in \\
\hline & 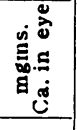 & 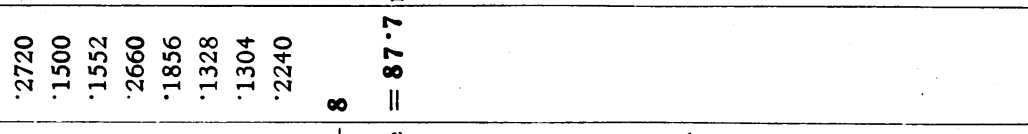 \\
\hline & 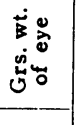 & 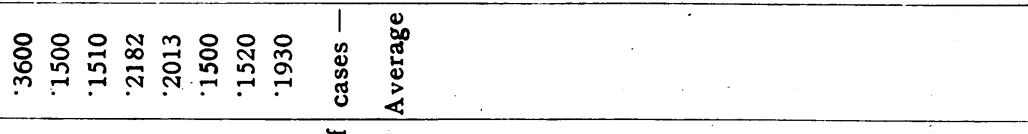 \\
\hline & $\begin{array}{l}\sum_{2}^{2} \dot{\delta} \\
\Sigma\end{array}$ & 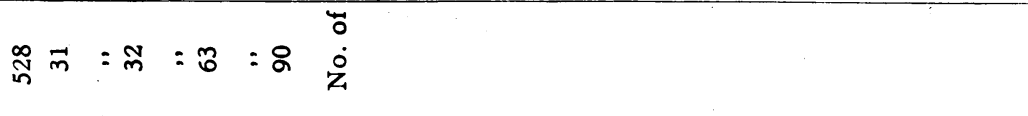 \\
\hline
\end{tabular}

